\title{
PROVISIONAL MEASURES AND CHILD ABDUCTION PROCEEDINGS
}

Summary: $\quad$ The purpose of the established system of the proceedings in cases of international child abduction, as set out in the Hague Convention on Child Abduction, which has been strengthened, in relation to the EU Member States, by the provisions of the Brussels II bis Regulation, is to secure a prompt return of the child that has been wrongfully removed or retained to his/her Member State of origin. The return of the child must provide full protection of the child both in the state where the child was unlawfully resident and in the state where the child has to return. In these respect, the competent authorities have at their disposal legal mechanisms for provisional and protective measures provided for by the Brussels II bis Regulation and the Hague Convention on Measures for the Protection of Children. The possibility of taking these measures will depend on the national law of the state in question and on the specific circumstances of the case. In this paper, a legal framework will be presented for the imposition of provisional measures in cases of cross-border child abduction, which will be supported by the case law of the Court of Justice of the European Union. Case examples gathered under the project "Cross-border removal and retention of a child - Croatian practice and European expectations" will illustrate the difficulties encountered by the courts in the Republic of Croatia when it comes to applying the relevant provisions.

Keywords: $\quad$ cross-border child abduction, Hague Convention on Child Abduction, Brussels II bis Regulation, Hague Convention on Measures for the Protection of Children, provisional and protective measures, Court of Justice of the European Union.

\footnotetext{
* $\quad$ Mirela Župan, PhD, Associate Professor, Chair for Public and Private International Law, Faculty of Law, Josip Juraj Strossmayer University of Osijek, Stjepana Radica 13, 31000 Osijek, Republic of Croatia. Email address: mzupan@pravos.hr. ORCID: https:// orcid.org/0000-0002-6673-1274

** Senija Ledić, MSc, judge, County Court in Split, Gundulićeva 29a, Republic of Croatia. Email address: Senija.Ledic@zsst. pravosudje.hr. ORCID: https://orcid.org/0000-0003-4919-1963

*** Martina Drventić, LLM, junior researcher at EUFam's project, Faculty of Law, Josip Juraj Strossmayer University of Osijek, Stjepana Radica 13, 31000 Osijek, Republic of Croatia. Email address: mdrventic@pravos.hr. ORCID: https://orcid.org/00000002-0880-0382
} 


\section{INTRODUCTION}

Provisional and protective measures, besides in civil and commercial matters, may be of particular importance in cross-border family disputes, if applied properly. ${ }^{1}$ Despite the fact that international treaties and regulations governing procedural issues in civil and commercial matters have been applied for decades, there are many outstanding issues in relation to proper application of provisional measures. They are also reflected in provisional measures in family matters concerning the definition of provisional measures, a proper structure of criteria pertaining to connecting factors, an ex parte system of provisional measures and the relationship and coordination with the substantive procedure. ${ }^{2}$ The aim of research carried out within the framework of the project "Cross-border removal and retention of a child - Croatian practice and European expectations" (hereinafter: Project) was to provide an overall scientific analysis of the practice of four Croatian municipal courts (Municipal Civil Court of Zagreb, Municipal Court of Split, Municipal Court of Rijeka, Municipal Court of Osijek) in the period from 1 July 2013 to 1 July $2017 .^{3}$ The objective of this research is to determine the number and manner of solving the cases and to analyse them statistically and scientifically, aiming at contributing to adaptation of the Croatian legislation to the international obligations assumed. The research showed that in the relevant period of time, 16 cases were conducted before those four courts on the basis of the Hague Convention on the Civil Aspects of International Child Abduction (hereinafter: Hague Convention on Child Abduction). ${ }^{4}$ In five cases, the court recorded the existence of provisional measures. Two were taken during the child abduction proceedings in the state where the child was habitually resident prior to removal. Three were taken in the state to which the child was unlawfully removed, two of which were taken before a request for the return of the child was lodged and one was taken during the child abduction proceedings. It was also documented that in two cases, during the decision-making process about the return of the child, the Croatian court had received a request for a provisional measure, which was rejected in both cases. The paper analyses court decision collected by the Project to determine which controversial issues regarding the application of the rules on provisional measures have been confirmed in relation to Croatian practice. This paper will also deal with the relationship of legal sources regulating provisional measures and their scope (2, 3), applicable law (4), procedural issues $(5,6)$ and protective measures in international child abduction proceedings (7). The content will be corroborated by the relevant practice of the Court of Justice of the European Union (hereinafter: CJEU).

1 Pertegás Sender, M., Article 20 Provisional, including protective measures, in: Magnus, U., Mankowski, P. (eds.), Brussels II bis Commentary, Sellier European Law Publishers, München, 2012, p. 248.

2 See: Honorati, C., Provisional Measures and the Recast of Brussels I Regulation: A Missed Opportunity for a Better Ruling, Rivista di diritto internazionale privato e processuale, Vol. 48, No. 3, 2012, pp. 525-544.

3 The project was funded through the internal call for proposals of J. J. Strossmayer University of Osijek for the application of scientific research and artistic projects for the program IZIP 2016. The principal investigator is Mirela Župan, PhD, Associate Professor, and the guest researcher, Professor Thalia Kruger, comes from the University of Antwerpen. Other Project associates are Martina Mikrut, PhD, Assistant Professor, Martina Drventić, Senija Ledić, MS, Marijana Šego, Mario Oreški and Danijel Rupić.

$4 \mathrm{HCCH}$, Hague Convention of 25 October 1980 on the Civil Aspects of International Child Abduction, https://www.hcch.net/en/ instruments/conventions/full-text/?cid=24. Haška konvencija o građanskopravnim aspektima međunarodne otmice djece od 25.10.1980, Official Gazette of SFRJ, International Treaties, No. 7/91. 


\section{LEGAL SOURCES OF PROVISIONAL MEASURES IN INTERNATIONAL CHILD ABDUCTION CASES}

The basis for dealing with cross-border child abduction cases is the Hague Convention on Child Abduction. It does not regulate any legal aspect of provisional measures, but merely provides for them in the chapter on central authorities, citing, as one of the special functions of central authorities, that they shall take all appropriate measures, either directly or through any intermediary, to prevent further harm to the child or prejudice to any of the interested parties by taking or initiating a provisional measure. ${ }^{5}$ The Republic of Croatia became a contracting party thereto on 8 October $1991 .^{6}$

Legal sources supplementing international child abduction cases, including provisional measures, are the Hague Convention of 1996 on Jurisdiction, Applicable Law, Recognition, Enforcement and Co-operation in Respect of Parental Responsibility and Measures for the Protection of Children (hereinafter: Hague Convention on Measures for the Protection of Children) ${ }^{7}$ and Council Regulation (EC) No 2201/2003 of 27 November 2003 concerning jurisdiction and the recognition and enforcement of judgments in matrimonial matters and the matters of parental responsibility, repealing Regulation (EC) No 1347/2000 (hereinafter: Brussels II bis Regulation). ${ }^{8}$

In relation to the Hague Convention on Child Abduction, the Hague Convention on Measures for the Protection of Children is a comprehensive instrument for the protection of children. ${ }^{9}$ While the Hague Convention on Child Abduction only provides for the possibility of initiating provisional measures, the Hague Convention on Measures for the Protection of Children contains rules on applicable law, rules on international jurisdiction and rules on recognition and enforcement. With regard to their mutual relationship, the provisions of the Hague Convention on Measures for the Protection of Children do not replace mechanisms established by the Hague Convention on Child Abduction, but supplement and strengthen them in some aspects. ${ }^{10}$ The Republic of Croatia became a contracting party to the Hague Convention on Measures for the Protection of Children on 1 January 2010.

Within the framework of common provisions, the Brussels II bis Regulation, which lays down jurisdiction and the recognition and enforcement of judgments in matrimonial matters and the matters of parental responsibility, contains a provision regulating provisional and

$5 \quad$ Ibid., Article 7(2)(b).

6 The Republic of Croatia became a contracting party pursuant to the Notification of Succession of 8 October 1991 - Official Gazette, International Treaties, No. 4/94

$7 \mathrm{HCCH}$, Convention of 19 October 1996 on Jurisdiction, Applicable Law, Recognition, Enforcement and Co-operation in Respect of Parental Responsibility and Measures for the Protection of Children, https://www.hcch.net/en/instruments/conventions/ full-text/?cid=70. Zakon o potvrđivanju Konvencije o nadležnosti, mjerodavnom pravu, priznanju, ovrsi i suradnji u odnosu na roditeljsku odgovornost i o mjerama za zaštitu djece, Official Gazette, International Treaties, No. 5/2009.

8 Council Regulation (EC) No 2201/2003 of 27 November 2003 concerning jurisdiction and the recognition and enforcement of judgments in matrimonial matters and the matters of parental responsibility, repealing Regulation (EC) No 1347/2000 [2003] OJ L 338.

9 Župan, M., Roditeljska skrb u sustavu Haške konvencije o mjerama dječje zaštite iz 1996., in: Rešetar, B. (ed.), Pravna zaštita prava na (zajedničku) roditeljsku skrb, Pravni fakultet Osijek, Osijek, 2012, pp. 199-222, p. 201.

10 Practical Handbook on the Operation of the 1996 Child Protection Convention, HCCH Publications, 2014, para. 13.1., https://www. hcch.net/en/publications-and-studies/details4/?pid=6096\&dtid=3, Accessed 19 September 2017. 
protective measures. ${ }^{11}$ The provisions of the Brussels II bis Regulation are also not used to change the provisions of the Convention on Child Abduction, but to supplement them. ${ }^{12}$ In relations between the EU Member States, the Brussels II bis Regulation takes precedence over the Child Abduction Convention to the extent to which it relates to the cases governed by the Brussels II bis Regulation. ${ }^{13}$ It has been in force in the Republic of Croatia since 1 July 2013.

A somewhat more complex mutual relationship exists between the Convention on Measures for the Protection of Children and the Brussels II bis Regulation. The Convention on Measures for the Protection of Children stipulates that it does not affect any international instrument which contracting parties are parties to and which contains provisions on matters governed by the Convention on Measures for the Protection of Children, unless the parties to that international agreement otherwise agree. ${ }^{14}$ The Brussels II bis Regulation regulates in more detail the relationship between these two instruments, prescribing that in legal relations involving the EU Member States, the Brussels II bis Regulation will take precedence in cases where a child is habitually resident in the territory of an EU Member State or in cases where the recognition and enforcement of a judgment given in one Member State are requested in another Member State, irrespective of the child's habitual residence. ${ }^{15}$ In matters not regulated by the Brussels II bis Regulation itself, the Hague Convention on Child Abduction and the Hague Convention on Measures for the Protection of Children shall apply. ${ }^{16}$

\section{THE SCOPE OF THE RELEVANT PROVISIONS ON PROVISIONAL MEASURES}

Given the lack of arrangements for provisional measures under the Hague Convention on Child Abduction, additional clarifications can be found in its accompanying documents. The Explanatory Report to the Child Abduction Convention explains that the ability of the central authorities to act varies from one Contracting State to another and that provisional measures are designed in particular to avoid another removal of the child. ${ }^{17}$ Thematically linked only to central authorities, the Guide to Good Practice elaborates this particular task in more detail. It states that depending on the limits of the powers vested in them, the central authorities should, at the very least, be able to alert other welfare or child protection agencies when a child is at risk, so that those agencies can take necessary protective measures. ${ }^{18}$ The conclusion of

11 Brussels II bis Regulation, op. cit., note 8, Article 20.

12 Pataut, E., Article 11 Return of the child, in: Magnus, U., Mankowski, P. (eds.), Brussels IIbis - Commentary, Sellier European Law Publishers, München, 2012, p. 128.

13 Brussels II bis Regulation, op. cit. note 8, Article 60(1)(e).

14 Convention on Measures for the Protection of Children, op. cit. note 7), Article 52(1).

15 Brussels II bis Regulation, op. cit. note 8, Article 61.

16 Ibid., Article 62(1).

17 Pérez-Vera, E., Explanatory Report on the 1980 Hague Child Abduction Convention, HCCH Publications, 1982, para. 91, https:// assets.hcch.net/upload/expl28.pdf. Accessed 17 September 2017.

18 Guide to Good Practice under the Hague Convention of 25 October 1980 on the Civil Aspects of International Child Abduction, Part I Central Authority Practice Part I, HCCH Publications, 2003, p. 52, https://assets.hcch.net/upload/abdguide_e.pdf. Accessed 17 September 2017. 
the Special Commission to Review the Operation of the Hague Convention is that Contracting States should ensure the availability of effective methods to prevent either party from removing the child prior to the decision on return. ${ }^{19}$

The Hague Convention on Measures for the Protection of Children distinguishes between two types of measures that can be imposed in international child abduction proceedings with respect to jurisdiction in relation to their imposition. ${ }^{20}$ These are measures for which the authority of the state where the child is habitually resident has jurisdiction (Article 5) and urgent protective measures that are imposed by the authority of the state where the child is unlawfully resident (Article 11). A comprehensive rule stipulates what measures directed to the protection of the person or assets of the child may in particular deal with: (a) the attribution, exercise, termination or restriction of parental responsibility, as well as its delegation; (b) rights of custody, including rights relating to the care of the person of the child and, in particular, the right to determine the child's place of residence, as well as rights of access including the right to take a child for a limited period of time to a place other than the child's habitual residence; (c) guardianship, curatorship and similar institutions; (d) the designation and functions of any person or body having charge of the child's person or property, representing or assisting the child; (e) the placement of the child in a foster family or in institutional care, or the provision of care by kafala or an analogous institution; (f) the supervision by a public authority of the care of a child by any person having charge of the child; and (g) the administration, conservation or disposal of the child's property. This list contained in Article 3 of the Convention on Measures for the Protection of Children is not complete, therefore it is difficult to find a measure that will not fall under the scope of this Convention, with the exception of those expressly excluded in Article $4 .{ }^{21}$ Provisional measures resulting from the general rule of jurisdiction based on the child's habitual residence are not limited by the rules of temporal or territorial validity. Pursuant to Article 14, they remain in force, even if a change of circumstances has eliminated the basis upon which jurisdiction was founded, so long as the authorities which have jurisdiction under the Convention have not modified, replaced or terminated such measures.

Urgent protective measures referred to in Article 11 may be taken by the authorities of any Contracting State in whose territory the child or assets belonging to the child are present, but only in cases of urgency. The Convention itself does not define the concept of urgency. It can be said that an emergency situation is a circumstance in which regular treatment pursuant to Articles 5 to 10 can cause irreparable damage to the child. The state of urgency therefore justifies the deviation from the usual rules and for this reason it should be interpreted quite strictly. ${ }^{22}$ The timeliness of these measures is limited to the period until the authorities competent under other rules of jurisdiction, i.e. the competent authorities of a non-Contracting State, take measures to remedy the situation.

19 Conclusions and Recommendations of the Fourth Meeting of the Special Commission to Review the Operation of the Hague Convention of 25 October 1980 on the Civil Aspects of International Child Abduction (22-28 March 2001), Conclusion 1.12., https://assets.hcch. net/upload/concl28sc4_e.pdf. Accessed 18 September 2017.

20 See generally: Lortie, P., An overview of the aims and central features of the 1996 Hague Convention on International Child Protection, in: Rešetar, B., Aras, S. (eds.), Represivne mjere za zaštitu osobnih prava i dobrobiti djeteta Interdisciplinarni, komparativni i međunarodni osvrti, Pravni fakultet Osijek, Osijek, 2014, pp. 221-227.

21 Župan, M., op. cit. note 9, p. 204.

22 Lagarde, P., Explanatory Report on the 1996 Hague Child Protection Convention, HCCH Publications, 1998, para. 68, https://www. hcch.net/en/publications-and-studies/details4/?pid=2943. Accessed 21 September 2017. 
In Article 20, the Brussels II bis Regulation recognises provisional and protective measures that the courts of a Member State may take in urgent cases in respect of persons or assets in that state. ${ }^{23}$ These measures shall cease to apply at the moment when the court of the Member State having jurisdiction under the Brussels II bis Regulation takes the measures it considers to be appropriate. In accordance with the interpretation of the CJEU in Case A., provisional measures within the meaning of Article 20 of the Brussels II bis Regulation are only those measures where three cumulative conditions are satisfied, i.e. the measures concerned must be urgent, must relate to persons and assets located in the forum state and must be provisional. ${ }^{24}$ The substantive scope of this provision is doubtful in legal literature. ${ }^{25}$ It is an open question whether Article 20 refers only to provisional and protective measures relating to the substantive scope of the Brussels II bis Regulation, or whether such measures may also relate to matters beyond its substantive scope. From the Explanatory Report on the Convention on Jurisdiction and the Recognition and Enforcement of Judgments in Matrimonial Matters (hereinafter: Brussels II Convention) it follows that, since provisional measures may be imposed in relation to persons and assets, they also concern matters not included in the scope of the Brussels II Convention. ${ }^{26}$ This claim is not confirmed by the interpretations of the Court of Justice of the European Union in cases De Cavel ${ }^{27}$ and W. $v$ H. ${ }^{28}$ in relation to provisional measures pertaining to the protection of matrimonial property. Today it is easier to offer an answer to the question of the substantive scope of the provision of Article 20, since provisional measures in matters most frequently associated with marital disputes and disputes over parental responsibility, such as the exercise of the maintenance right and matters of marital property regimes, are legally regulated by the separate regulations. ${ }^{29}$

\section{APPLICABLE LAW}

The question of the law applicable to taking provisional measures can be found only in the provisions of the Hague Convention on Measures for the Protection of Children. Pursuant to Article 15, the law applicable to protective measures is law of the forum (lex fori). This rule applies irrespective of the grounds on which jurisdiction is based and is justified by the fact that the application of law of the forum makes it easier for the authorities to operate since

23 The Convention on Measures for the Protection of Children provides for the possibility of imposing measures in relation to the child and assets, the Brussels II bis Regulation provides for the imposition of provisional measures in relation to persons and assets. In the Proposal for a recast of the Brussels II bis Regulation of June 2016, the word "person" is replaced by the word "child", harmonising in this way its content with the Convention on Measures for the Protection of Children. See also: Drventić, M., New Trends in European Family Procedural Law, in: Duić, D., Petrašević, T. (eds.), Procedural Aspects of EU Law, Pravni fakultet Osijek, Osijek, 2017, pp. 424-447, p. 433.

Case C-523/07, A, [2009], ECLI:EU:C:2009:225, para. 47.

25 Pertegás Sender, M., op. cit. note 1, p. 250.

26 Explanatory Report on the Convention, drawn up on the basis of Article K.3 of the Treaty on European Union, on Jurisdiction and the Recognition and Enforcement of Judgments in Matrimonial Matters (approved by the Council on 28 May 1998) prepared by Dr Alegría Borrás, [1998] OJ C 221/27, para. 59. 
they apply the law they know best, and since ultimately protective measures will primarily be taken in the state imposing them. ${ }^{30}$ Exceptionally, in so far as the protection of the person or the property of the child requires, the court may exceptionally apply or take into consideration the law of another state with which the situation has a substantial connection. ${ }^{31}$ Similarly, if the child's habitual residence changes to another Contracting State, the law of that other state governs, from the time of the change, the conditions of application of the measures taken by the former authority. ${ }^{32}$

\section{INTERNATIONAL JURISDICTION}

\subsection{RULES ON JURISDICTION}

In provisions on jurisdiction, the Hague Convention on Measures for the Protection of Children favours the courts and authorities of the child's habitual residence. ${ }^{33}$ The basic rule of jurisdiction contained in Article 5 stipulates that the judicial or administrative authorities of the Contracting State of the child's habitual residence have jurisdiction to take measures directed to the protection of the child's person or property. The same article contains an exception according to which, in case of a change of the child's habitual residence to another Contracting State, the authorities of the state of the new habitual residence shall have jurisdiction. However, a change of the child's habitual residence will not lead to a change of international jurisdiction if child relocation is unlawful. In accordance with Article 7, in case of wrongful removal or retention of the child, the authorities of the Contracting State in which the child was habitually resident immediately before the removal or retention keep their jurisdiction. Exceptionally, the authorities of another State would have jurisdiction if a person, institution or other authority having rights of custody has acquiesced in the removal or retention, or if the child has resided in that other state for a period of at least one year after the person or institution having rights of custody has or should have had knowledge of the whereabouts of the child, no request for the return lodged within that period is still pending, and the child is settled in its new environment. ${ }^{34}$ By this solution, the Hague Convention on Measures for the Protection of Children reinforces the effects of the Hague Convention on Child Abduction, stating that the removal of a child to another state does not provide for jurisdiction of the authorities in that state on parental responsibility or contacts. ${ }^{35}$ The same solution applies in relation to the EU Member States in accordance with Article 10 of the Brussels II bis Reglation. ${ }^{36}$

30 Župan, M., op. cit. note 9, p. 212.

31 Convention on Measures for the Protection of Children, op. cit. note 7), Article (15)(2).

32 Ibid., Article (15)(3).

33 Župan, M., op. cit. note 9, p. 205.

34 Convention on Measures for the Protection of Children, op. cit. note 7, Article 7(1).

35 Župan, M., op. cit. note 9, p. 208.

36 See: Lazić, V., Legal Framework for International Child Abduction in the European Union - the Need for Changes in the Light of Povse $v$. Austria, in: Župan, M. (ed), Private International Law in the Jurisprudence of European Courts - Family at Focus, Pravni fakultet Osijek, Osijek, 2015, pp. 295-316. 
Despite the above-mentioned rules, the authorities of the state of a new unlawful habitual residence of the child have the ability to adopt urgent protective measures. Their jurisdiction is based on Article 11 of the Hague Convention on Measures for the Protection of Children, which stipulates that the authorities of any Contracting State in whose territory the child or property belonging to the child is present shall have jurisdiction to take any necessary measures of protection, provided that it is a case of urgency and with a time limit set for such measures that shall cease to apply at the moment when the authorities of the state of the child's habitual residence take the measures they consider to be appropriate.

In its Article 20, the Brussels II bis Regulation also enables deviation from the rules of jurisdiction, prescribing that in urgent cases, the courts of a Member State may take provisional, including protective, measures in respect of persons or assets in that state even if the court of another Member State has jurisdiction as to the substance of the dispute. ${ }^{37}$ It is suggested that, in order to make the grounds of jurisdiction clearly evident, whenever a court takes such measure it should state in limine of the judgment whereby the measure is taken whether it has jurisdictional competence under the Regulation on the substance of the process or whether it has not. ${ }^{38}$

The fact that the Croatian authorities are not aware of the possibility of imposing provisional and protective measures under Article 20 of the Brussels II bis Regulation is confirmed by a recent case from the Municipal Court of Split, ${ }^{39}$ which ruled on the request of the father to return the unlawfully removed child to Slovenia. The father claims that he did not give the child's mother permission to remove the child to Croatia. The mother stated in the court that she was a victim of domestic violence and hence stayed for a while at a safe house in Slovenia. The Croatian court found out in the return proceedings that, based on the request the father lodged before the competent court in Slovenia to award custody of the child to him, a provisional measure was adopted by which the child was entrusted in the mother's care and the father was granted with the contact rights. Likewise, the court also stated that a court settlement on a visitation schedule between the father and the mother regulating the time the father spends with the child was concluded before the competent Slovenian court shortly thereafter. Since father continued to harass the mother and the child during the proceedings in Croatia, the mother requested the adoption of a provisional measure before the court in Croatia as to who the child would live with and how the contacts with the other parent would be arranged. The court declared that it has no jurisdiction as to the adoption of a provisional measure, explaining that by the fact that the child was habitually resident in Slovenia before abduction, that the parental responsibility proceedings were conducted before the Slovenian court, and that there already exists a provisional measure regulating visitation and contacts. The Appeal Court confirmed the contested decision. A provisional measure and the settlement made before the Slovenian authorities do not produce any legal effect in Croatia without the recognition procedure carried out, so it is wrong to refer to them in the explanation as one of the reasons for not imposing a provisional measure in Croatia. The court could have found

37 See: McEleavi, P., The New Child Abduction Regime in the European Union: Symbiotic Relationship or Forced Partnership?, Journal of Private International Law, Vol. 1, No. 1, 2005, pp. 5-34, p. 11.

38 Practice Guide for the Application of the Brussels IIa Regulation, p. 23, http://ec.europa.eu/justice/civil/files/brussels_ii_practice_ guide_hr.pdf. Accessed 20 September 2017. 
the grounds for action at the request of the mother for the adoption of a provisional measure in Article 20 of the Brussels II bis Regulation or explained its reasons for not adopting the measure by other facts.

In the proceedings for the return of the child brought from France to Croatia by its mother, when deciding on the father's request for the adoption of a provisional measure to regulate his contact with the child in Croatia, the Municipal Civil Court of Zagreb has decided not to impose a provisional measure, arguing that the petitioner has no legal interest in the imposition thereof. ${ }^{40}$ The Appeal Court accepted the appeal filed by the appellant and revoked the decision in which the court refused to issue a provisional measure and remanded the case to the Municipal Civil Court instructing it to state the reasons for rejecting the proposal. ${ }^{41}$ The two instances were without prejudice to their jurisdiction, although in the explanatory statement, authorisation to issue a provisional measure was not based on Article 20 of the Brussels II bis Regulation. In fact, the courts did not make any referral to the grounds of jurisdiction for issuing such a provisional measure. It is to be assumed that they were not considering the cross-border element and by this had been guided by the national rules. ${ }^{42}$

\subsection{RELATIONSHIP BETWEEN THE GENERAL JURISDICTION PROVISIONS AND THE PROVISION OF ARTICLE 20 OF THE BRUSSELS II BIS REGULATION. CASE DETIČEK V SGUEGLIA.}

The relationship between a general jurisdiction rules based on the child's habitual residence and special authorisation to take provisional measures referred to in Article 20 of the Brussels II bis Regulation, which has repeatedly been problematic in national practice, has been further regulated by the Court of Justice of the European Union with its interpretation in the Detiček v Sgueglia case, following the request for a preliminary ruling from the High Court of Maribor. ${ }^{43}$ The judgement is related to the dispute between Ms Detiček and Mr Sgueglia concerning custody of their daughter Antonella. In June 2007, the competent court in Tivoli (Italy), before which divorce proceedings were pending between Ms Detiček and Mr Sgueglia, provisionally granted custody of the child to Mr Sgueglia and ordered temporarily placement of the daughter in the children's home in Rome. On the same date the mother left Italy with the child and went to Slovenia. Shortly afterwards, Mr Sguiglia requested the Slovenian authorities to recognise and declare enforceable the order by the Italian court, which was done by the competent court in Slovenia, in accordance with the Brussels II bis Regulation. By judgment of November 2007 of the Regional Court of Maribor, the order of the court in Tivoli was declared enforceable in the territory of the Republic of Slovenia, which was also confirmed by the judgment of the Supreme Court of the Republic of Slovenia in October 2008. Meanwhile, Ms Detiček made an application to the court in Maribor for a provisional and

\footnotetext{
40 Municipal Civil Court of Zagreb (Općinski građanski sud u Zagrebu), No. 144-R1 Ob-830/16-43 from 31 January 2017.

41 County Court of Zagreb (Županijski sud u Zagrebu), No. 68 Gž Ob-400/17-2 from 10 April 2017.

42 See: Župan, M., Drventić, M., Kindesentführung vor kroatischen Gerichten mit besonderer Rücksicht auf die aus Deutschland kommenden Anträge, Revija za evropsko pravo, Vol. 20, No. 1., 2018, pp. 63-83. 
protective measure giving her custody of the child. By order of December 2008, the Regional Court of Maribor allowed Ms Detiček's application and granted her provisional custody of the child. The Court based its decision on Article 20 of the Brussels II bis Regulation in conjunction with Article 13 of the 1980 Hague Convention on Child Abduction, on the grounds of change of circumstances and the best interests of the child. Mr Sgueglia appealed to the same court against that order, which dismissed his action in June 2009. After that, he appealed to the High Court. The High Court decided to stay the proceedings and refer the question to the Court of Justice of the European Union for a preliminary ruling as to whether a court of the Republic of Slovenia, has jurisdiction under Article 20 of the Brussels II bis Regulation to take provisional and protective measures in a situation in which a court of another Member State, having jurisdiction as to the substance, has already taken a protective measure declared enforceable in the Republic of Slovenia. The Court explains that Article 20 is an exception to the rule of general jurisdiction laid down in Article 8 of the Brussels II bis Regulation, which should be interpreted restrictively and which can only be applied on condition that three cumulative conditions are satisfied, i.e. the measures concerned must be urgent, must relate to persons and assets located in the forum state and must be provisional. The Court considers that none of the conditions were met in the Detiček case. The Court finds that the circumstances mentioned by the Regional Court of Maribor when it ordered a provisional measure are not grounds for finding that the case is urgent. If such circumstances were treated as an urgency situation, one would run counter to the principle of mutual recognition of judgments given in the Member States, given that a provisional measure adopted in Italy is recognised before the competent Slovenian authorities. ${ }^{44}$ The Court explains that a provisional measure granting custody of a child is taken not only in respect of the child, but also in respect of the parent to whom custody of the child is granted and of the other parent who is deprived of that custody. In this case, the father, as one of the parties in respect of whom such a measure is taken, resides in a Member State other than the forum state. ${ }^{45}$ Finally, the court also considers the issue of a child maintaining direct contact with both parents in the light of Article 24 of the Charter of Fundamental Rights of the European Union, ${ }^{46}$ and concludes that Article 20 of the Brussels II bis Regulation cannot be interpreted in such a way that it can be used by the parent who has wrongfully removed the child as an instrument for prolonging the factual situation caused by his or her wrongful conduct or for legitimating the consequences of that conduct. ${ }^{47}$ In the light of all the above considerations, the Court decided that Article 20 must be interpreted as not allowing, in circumstances such as those of the main proceedings, a court of a Member State to take a provisional measure in matters of parental responsibility granting custody of a child who is in the territory of that Member State to one parent, where a court of another Member State, which has jurisdiction as to the substance of the dispute, has already delivered a judgment provisionally giving custody of the child to the other parent, and that judgment has been declared enforceable in the territory of the former Member State.

\footnotetext{
44 Ibid., para. 45-49.

45 Ibid., para. 50-52.

46 "Every child shall have the right to maintain on a regular basis a personal relationship and direct contact with both his or her parents, unless that is contrary to his or her interests." Charter of Fundamental Rights of the European Union, [2007], OJ C 303/1. 
By its strict interpretation of the requirements that needs to be met in order to apply the Article 20 of the Brussels IIbis Regulation, the CJEU had manifestly advocated the rules of the Hague Convention on Child Abduction and Brussels II bis Regulation that are fighting against the child abduction. Still, it is considered that the condition on geographical scope suggesting that all the parties must be in the State in which the provisional measure is request, is to restrictive. It leads toward the situation where no provisional measure could be issued if one parent is in another country.

\section{THE RECOGNITION AND ENFORCEMENT OF PROVISIONAL MEASURES}

Pursuant to Article 23 of the Convention on Measures for the Protection of Children, measures for the protection of children taken in one Contracting State will be recognised by operation of law in other Contracting States. It is not necessary to commence proceedings in the Contracting State requiring the recognition of measures for them to produce their effects there. ${ }^{48}$ However, in order for a measure to be recognised, its existence may need to established in the requested Contracting State. To avoid placing bureaucratic hurdles in the way of the protection of children, the Convention does not have any formal requirements in this regard. ${ }^{49}$ Article 23(2) contains an exhaustive list of reasons for which recognition may be refused: (i) if the measure was taken by an authority whose jurisdiction was not based on one of the grounds provided for in Chapter II; (ii) if the measure was taken, except in a case of urgency, in the context of a judicial or administrative proceeding, without the child having been provided the opportunity to be heard, in violation of fundamental principles of the procedure of the requested State; (iii) on the request of any person claiming that the measure infringes his or her parental responsibility, if such measure was taken, except in a case of urgency, without such person having been given an opportunity to be heard; (iv) if such recognition is manifestly contrary to public policy of the requested State, taking into account the best interests of the child; (v) if the measure is incompatible with a later measure taken in the non-Contracting State of the habitual residence of the child, where this later measure fulfils the requirements for recognition in the requested State; and (vi) if the procedure provided in Article 33 has not been complied with. When it comes to enforcement, measures taken and enforceable in one Contracting State shall, upon request by one of the interested parties, be declared enforceable or registered for the purpose of enforcement in that other state. The declaration of enforceability or registration may be refused only for the same the reasons recognition may be refused for. In such procedures, the Convention prohibits any review of the merits of the measure taken. ${ }^{50}$

Recognition and enforcement rules apply to all jurisdictional regimes, including urgent protective measures referred to in Article 11. Article 11 gives the judge rendering a decision on a request for the return the possibility of taking urgent protective measures when there

\footnotetext{
48 Practical Handbook on the Operation of the 1996 Child Protection Convention, op. cit. note 10, para. 10.1.

49 Ibid., para. 10.2.

50 Convention on Measures for the Protection of Children, op. cit. note 7, Article 27.
} 
is a possibility that the child's return is expected to encounter a serious risk of harm. The advantage of these measures is that they give assurance to a judge that they will be recognised and enforceable in the state the child is to return to, in the period immediately following the child's return. ${ }^{51}$ For example, a judge may impose a measure that would enable a parent from whom the child was removed due to allegations of domestic violence, following the return to its state of habitual residence, to visit the child only under the supervision of a Social Welfare Center officer.

The rule on provisional and protective measures referred to in Article 20 of the Brussels II bis Regulation is limited in terms of recognition and enforcement. ${ }^{52}$ Unlike Article 11 of the Convention on Measures for the Protection of Children, it does not constitute the rule of jurisdiction but is contained in the chapter containing common provisions, meaning that the rules on the recognition and enforcement of decisions under Brussels II bis Regulation do not apply thereto

A more detailed interpretation of this question was given by the court in the Purrucker case $^{53}$, following the request for a preliminary ruling from the German Federal Court. The judgment concerned Mr Purrucker and Mr Vallés Pérez. In mid-2005, Ms Purrucker went to Spain to live with Mr Vallés Pérez. In May 2006, she gave birth to twins who were born prematurely. The boy, Merlín, was able to leave hospital in September 2006. The girl, Samira, could do so only in March 2007, after intervening complications. By that time, the relationship between Ms Purrucker and Mr Vallés Pérez had deteriorated. Ms Purrucker wanted to return to Germany with the children, while Mr Vallés Pérez was opposed to this. In January 2007, the parties signed an agreement before a notary according to which the children will live in Germany with the mother but the parents will both have joint custody, and the father can freely exercise his right of access to his children. The agreement had to be approved by a competent court in order to be enforceable. Ms Purrucker intended to return to Germany with her son D., the child of a previous relationship, and her children Merlín and Samira. However, due to complications and the need for surgery, the child Samira could not leave hospital. In February 2007, Ms Purrucker left for Germany with her son Merlín and according to her statements in the proceedings, her daughter was also to be brought to Germany after she left hospital. Since Mr Vallés Pérez no longer felt bound by the agreement signed before a notary, in June 2007 he brought proceedings before the court of first instance in San Lorenzo de El Escorial to obtain the granting of the provisional measure and rights of custody of the children Samira and Merlín. By the judgment delivered in November 2007, the Spanish Court adopted the provisional measure granting the father custody of both children, while the mother was ordered to return Merlín to Spain and was allowed to visit her children at any time whenever she wishes to do so. In January 2008, the Spanish court issued a certificate pursuant to Article 39 of the Brussels II bis Regulation. In addition to requesting the return of Merlín to Spain, Mr Vallés Pérez also brought proceedings in Germany concerning the enforcement of the judgment of the Court

51 Beaumont, P., Walker, L., Holliday, J., Conflicts of EU Courts on Child Abduction: The reality of Article 11(6)-(8) Brussels IIa proceedings across the EU, Journal of Private International Law, Vol. 12, No. 2, 2016, pp. 211-260.

52 Beaumont, P., Walker, L., Holliday, J., Parental responsibility and international child abduction in the proposed recast of Brussels IIa Regulation and the effect of Brexit on future child abduction proceedings, International Family Law Journal, Vol. 4, 2016, pp. 307318. 
in San Lorenzo de El Escorial granting a provisional measure. On 3 July 2008, the District Court in Stuttgart ordered the execution of the judgment of the Spanish court, which was confirmed by the Appeal Court in Stuttgart by a decision on appeal of 22 September 2008, and warned the mother that she could be fined if she did not comply with the order. Ms Purrucker brought the appeal before the Federal Court challenging the judgment of the Appeal Court in Stuttgart of 22 September 2008. The Federal Court decided to stay the proceedings and refer the question to the Court of Justice of the European Union for a preliminary ruling whether the provisions of Article 21 et seq. of the Brussels II bis Regulation concerning the recognition and enforcement of decisions of other Member States, in accordance with Article 2(4) of that regulation, apply to enforceable provisional measures taken within the meaning of Article 20 of the Brussels II bis Regulation, concerning the right to child custody. ${ }^{54}$ At the very beginning, the relevance of the question is challenged by the Court of Justice of EU. The provisional measure concerned in the Purrucker case does not fall within the scope of Article 20 of the Brussels II bis Regulation since it was taken by a court which had jurisdiction as to the substance of the matter. Moreover, even if this measure had been taken by a court which did not have jurisdiction as to the substance of the matter, it could not in any event fall within the scope of Article 20 in so far as it related to Merlín, since he was not in Spain when the Court in San Lorenzo de El Escorial delivered its judgment. ${ }^{55}$ Furthermore, the Court explains that, as is evident from the position of Article 20 in the structure of the Regulation itself, it cannot be regarded as a provision which determines substantive jurisdiction. ${ }^{56}$ The Court explains that the position of the provision of Article 20, its content and the content of Recital 16 show that provisional, including protective, measures within the scope of Article 20 do not fall into the category of judgments adopted in accordance with the rules of jurisdiction laid down by the Regulation and hence neither under the recognition and enforcement system established by the Regulation. ${ }^{57}$ The fact that the provisional measures referred to in Article 20 of the Regulation do not fall under the recognition and enforcement rules prescribed by the Regulation, will not affect the possibility of their recognition and enforcement in the Member States in accordance with other international instruments, as long as they comply with the Regulation. ${ }^{58}$

The question arises as to whether Article 11 of the Convention on Measures for the Protection of Children shall apply when the child is habitually resident in an EU Member State? More specifically, in relation to the mutual legal relationship between two instruments, does Article 11(1) of the Convention on Measures for the Protection of Children fall under the heading "matters not regulated by the Brussels II bis Regulation"? ${ }^{59}$ In its interpretation in the Purruker case, the Court did not give a completely clear answer to this question, although its positive attitude to the possibility of applying the provisions of the Hague Convention on Measures for the Protection of Children can be implied in its reasoning.

54 The Court did not agree with the opinion of Advocate General Sharpstone, according to which provisional measures imposed by the competent court under the provisions of the Brussels II bis Regulation may be recognised and enforced in other Member States in the same way as any other decision rendered on the basis of the same facts, in accordance with Article 21 of the Brussels II bis Regulation. See: Case C-256/09 Opinion of Advocate General Sharpston delivered on 20 May 2010. ECLI:EU:C:2010:296.

Case C-256/09, op. cit. note 41, para. 58.

Ibid., para. 60-61.

Ibid., para. 87.

Ibid., para. 92.

Beaumont, P., Walker, L., Holliday, J., op. cit. note 51, p. 13 
The aforementioned situations could eventually be resolved by the Commission Proposal to recast the Brussels II bis Regulation of 2016, ${ }^{60}$ which favours the solution offered by the Convention on Measures for the Protection of Children. The Proposal moves the provision referring to provisional measures to the chapter on jurisdiction, and in a special provision contained in Article 48 it unambiguously states that the provisions of Chapter IV on the recognition and enforcement apply to provisional, including protective, measures determined by the competent authority under the jurisdiction rule. ${ }^{61}$

The practice of national courts has confirmed lack of understanding of the legal effects of provisional measures taken in another Member State. In one of the examples, the Municipal Court of Osijek acted upon the request of the petitioner for the return to Germany of a minor daughter unlawfully taken to Croatia by her mother for reasons of domestic violence against her and the child. In the course of the return proceedings, the father obtained a provisional measure in Germany entitling him to decide on the place of residence of the child. After having conducted the proceedings, the Croatian court decided to order the mother to return the child to the father to the place of her habitual residence in Germany, explaining that the conditions for the application of Article 13(1)(b) of the Convention have not been met, referring also to the provisional measure adopted in Germany as an additional reason for rendering a decision ordering the return of the child. ${ }^{62}$ The provisional measure in matter was issued in the state of child's habitual residence and it was not recognised in the Republic of Croatia. In order to gain the legal force in the Republic of Croatia the measure needed to be recognised upon the Article 23 of the Hague Convention of on Measures for the Protection of Children. Otherwise, the measure was not effective in the Republic of Croatia. The Court of Appeal stressed in its reasoning that German provisional measure lacked the legal force in Croatia. ${ }^{63}$

\section{PROTECTIVE MEASURES}

\subsection{MEASURES SECURING THE RETURN OF A CHILD}

During the return proceedings, it is necessary for the court and other competent authorities to ensure the safety and well-being of the child to the maximum extent possible. In these proceedings, we should distinguish between the measures taken in the requested State in or-

60 Proposal for a Council Regulation on jurisdiction, the recognition and enforcement of decisions in matrimonial matters and the matters of parental responsibility, and on international child abduction (recast), Bruxelles, 30.6.2016. COM(2016) 411 final 2016/0190 (CNS).

61 See: Kruger, T., Enhancing Cross-Border Cooperation, Recasting the Brussels IIa Regulation, Workshop 8 November 2016, Compilation of briefings for the JURI Committee, 2016, pp. 36-45, p. 38, URL: http://www.europarl.europa.eu/RegData/etudes/ STUD/2016/571383/IPOL_STU(2016)571383_EN.pdf. Accessed 25 September 2017 and Kruger, T., Samyn, L., Brussels IIbis: successes and suggested improvements, Journal of Private International Law, Vol. 12, No. 1, 2016, pp. 132-168.

62 Municipal Court of Osijek (Općinski sud u Osijeku), No. 12 R1 Ob-566/2016-26 from 3 October 2016 (INCADAT cite: HC/E/HR 1394).

63 County Court of Zagreb (Županijski sud u Zagrebu), No. 1 Gž Ob-1456/2016-2 from 2 December 2016 (INCADAT cite: HC/E/ HR 1395). 
der to protect the child during the return proceedings, and the measures taken in the requesting State in order to protect the child upon his or her return to the requesting State. ${ }^{64}$

Article 11(4) of the Brussels II bis Regulation stipulates that a court cannot refuse to return a child on the basis of Article 13(b) of the 1980 Hague Convention on Child Abduction if it is established that adequate arrangements have been made to secure the protection of the child after his or her return. The provision, consistent with the principle of mutual trust between Member States, promotes the dialogue between judges and officials of the EU Member States to ensure that appropriate provisional measures are taken when necessary. ${ }^{65}$ Research conducted showed that, out of eight decisions made in the EU Member States ${ }^{66}$ which were decided upon in the relevant period by the courts included in research, in six cases the court rejected the petitioner's request for the returning of the child pursuant to Article 13(1)(b), in one case the court ordered the return of the child and in one case the judge rejected the request as inadmissible. It has been noted that only in one case, out of six, the court has verified that the adequate arrangements have not been made by the applicant in order to secure the protection of the child after his or her return. In another case, the court requested the data referred to in Article 11(4) of the Brussels II bis Regulation, but has not received any from the central authority of the requesting State by the judgment delivery date, and hence could not use them in the proceedings prior to judgment delivery.

In order to secure the prompt and safe return of the child, the courts ruling on requests for the return of children have at their disposal options such as mirror orders, the so-called safe harbour orders and undertakings, where the possibility of enforcement in the state the child is returned to is always uncertain. In the states that are contracting parties to the Hague Convention on Measures for the Protection of Children, the issue relating to enforcement in the other Contracting State is not questionable when adopting the measures referred to in Article $11{ }^{67}$ The question as to whether and what kind of measure shall be taken depends on the particular circumstances of the case and the national law of the state in question.

Although the Child Abduction Convention does not mention them, a positive aspect of these measures is found in common law systems in the form of undertakings. They can be voluntarily taken by the left-behind parent or their adoption may be requested by the court that decides on the return request. ${ }^{68}$ Schuz lists five types of measures, arising from court practice, which can be brought in these situations: (i) financial and material measures, e.g. travel expenses for return purposes; (ii) measures aimed at preventing the initiation or continuation of criminal proceedings against a parent who abducted the child after his or her return, e.g. the obligation of the parent from whom the child was removed not to institute criminal proceedings, or to withdraw a lawsuit against the parent who removed the child; (iii) measures relating

64 Draft Guide to Good Practice on Article 13(1)(b) of the Hague Convention of 25 October 1980 on the Civil Aspects of International Child Abduction, Seventh Meeting of the Special Commission on the Practical Operation of the 1980 Child Abduction Convention and the 1996 Child Protection Convention (10-17 October 2017), p. 34. https://assets.hcch.net/docs/0a0532b7-d580-4e53-8c257edab2a94284.pdf, Accessed 27 September 2017.

65 Beaumont, P., Walker, L., Holliday, J., op. cit. note 51, p. 221.

66 Judgements at first instance were taken into consideration, regardless of the outcome of the appeal procedure in some of the cases.

67 Draft Guide to Good Practice on Article 13(1)(b) of the Hague Convention of 25 October 1980 on the Civil Aspects of International Child Abduction, op. cit. note 64, p. 35. 
to parental care proceedings under way in the state where the child is to be returned, e.g. if the parent from whom the child was removed before or during the return proceedings obtains a decision granting parental care to him, (s)he may be obliged not to enforce that decision until the proceedings relating to the substance of the matter are concluded; (iv) measures aimed at preventing the violence of the parent from whom a child was removed against the returning child and parent, e.g. prohibition of access to the returning parent, and sometimes to the returning child without permission issued by the court of the returning state, and finally, (v) the measure by which the parent from whom the child was removed may commit to initiate the proceedings for making a decision on parental care and the state where the child returns immediately upon the child's return.

The aforementioned case of the Municipal Court of Osijek ${ }^{69}$ was the only of eight EU cases in which the court ordered the return of the child to the father habitually resident in Germany. According to the circumstances of the case, the mother was a victim of domestic violence in Germany. She reported violence to the German police and stayed at a safe house in Germany for some time before coming to Croatia. It is unknown whether the mother has proven the existence of domestic violence before the court in Croatia, but it is clear that the court did not request any delivery of reports by the German authorities about the circumstances, which it was authorised to do on the basis of Article 13 of the Child Abduction Convention. A special guardian appointed to represent a child in court proceedings emphasised in the course of the proceedings that, if the child were to return to the Germany, the court should seek guarantees from the competent German authority aimed at securing the conditions for the return of the mother and the child to Germany. The court did not accept the opinion of a special guardian, and despite the existence of legitimate reasons for more careful handling of the case, it ruled that the child should be returned to the father, together with her travel document. Indiscriminate treatment of the court was confirmed later in the case. The appeal court annulled the first-instance judgment and returned the case for a retrial, and before the judgment was delivered in the repeated trial, the father, when he came into direct contact with his child during his visitation time in Croatia, took the child to Germany without the mother's permission. The above circumstances indicated that the court had the grounds for seeking a guarantee, but also for the adoption of a provisional measure under Article 20 of the Brussels II bis Regulation which would protect the child during the child return proceedings, such as measure of exercising the contact of a child and a father in a presence of a expert workers from the Social Welfare Centre.

\subsection{PROTECTIVE MEASURES IN THE CHILD RETURN PROCEEDINGS IN THE LEGAL SYSTEM OF THE REPUBLIC OF CROATIA}

In the legal system of the Republic of Croatia, in the proceedings in which it decides on family and status related matters ${ }^{70}$ the court is obliged to pay special attention to the protection of the rights and interests of children under the provisions of Article 348(1) of the Family Act. ${ }^{71}$ In matters of status, decisions relating to parental care, personal relationships

\footnotetext{
69 Municipal Court of Osijek, op. cit. note 62.

70 Special litigation proceedings, non-litigation proceedings, special enforcement and assurance proceedings.

71 Family Act (Obiteljski zakon), Official Gazette, No. 103/15.
} 
and measures to protect the rights and well-being of a child it is also authorised to determine the facts the parties have not presented (Article 350). Moreover, the proceedings relating to delivering judgments on the rights of the child are urgent, ${ }^{72}$ in certain cases when deciding on the rights and welfare of the child, the court is empowered to act ex officio ${ }^{73}$ and without oral hearing, ${ }^{74}$ e.g. in special security proceedings when deciding on:

1. a provisional measure relating to the parent the child shall live with, the child's habitual residence and personal relations with the child,

2. a provisional measure for maintenance; these provisional measures can be imposed before the initiation of and during the court proceedings in which the relationship ensured by the provisional measure is determined..$^{75}$

When it comes to the process of establishing the child's personal relationship with a parent or the procedures preventing the unlawful removal of a child by a parent entitled to the right to maintain a personal relationship and direct contact with a child, the Family Act also provides for measures to ensure the return of the child, and these are:

1. to impose an obligation to turn in a passport to a court that imposed the measure in the course of maintaining a personal relationship and direct contact with a child;

2. to impose an obligation of a security deposit to a parent entitled to the right of maintaining a personal relationship and direct contact with a child;

3. to impose a ban on alienation or burden of property rights by the annotation and entry of a ban in public registers;

4. to impose an obligation to a parent maintaining a personal relationship and direct contact with a child to report regularly with the child to the competent authority, such as a social welfare center or a police station in the place where personal relationships are maintained;

5. to determine the place where personal relationships are to be maintained;

6. to prohibit the departure of a child from the state in which personal relationships are to be maintained and to enter the ban into a national or cross-border information system. ${ }^{76}$

The protection of the child upon the return is the mail task of the judicial and other authorities of the Member States in the cross-border proceedings concerning the child's rights. By the detailed measures listed above by which the Family Act provides for the safe return of a child, the protection of a child is guaranteed at the national level, but as well it is guaranteed in the cases conducted upon the Hague Child Abduction Convention. These measures by its content and legal scope, are contributing to the principles of mutual trust between the national legal system and national judicial authorities and the judicial systems and judicial authorities of other Member States in cross-border proceedings concerning the rights of the children.

\footnotetext{
72 Ibid., Article 347(1) - the principle of urgency, one of the fundamental principles of court proceedings under the Family Act.

73 Ibid., Article 530(4).

74 Ibid., Article 531.

75 Ibid., Article 529.

76 Ibid., Article 419(1).
} 
For the same reasons, it is acceptable to conclude that in the Republic of Croatia, the Enforcement $\mathrm{Act}^{77}$ as a general regulation regulating the assurance proceedings, in particular the assurance by a provisional measure, is in force as a legal source for taking the necessary measures for the protection of the child upon his or her return. Namely, the task of provisional measures in modern conditions has been substantially altered. Its classical function is to create the conditions for the future realisation of creditor claims based on a decision that will be or has already been made in the main proceedings. In addition a different, new function has been accomplished. This function has its roots in the European and Croatian legislation and judiciary and has been gaining importance. It is a function of a fast and temporary arrangement of the relations between the parties involved in the dispute in order to establish legal peace, defined as a regulatory function. Its essence is in the court's authority to arrange certain legal relationships temporarily, more or less, according to their free judgment. ${ }^{78}$ In so doing, the freedom of assessment in relation to protective measures in child return proceedings would depend on the need to protect children and the need for mutual trust in the legal systems of the EU Member States.

Assurance by a provisional measure as a protective measure in child return proceedings can be particularly efficient in cases when it is necessary to prevent violence. Likelihood that a provisional measure will be needed to prevent violence is one of the alternative prerequisites needed to impose a provisional measure to ensure non-cash claims. ${ }^{79}$ The other likelihood is the existence of a claim, which would be a return decision in child return proceedings.

While the provisions of the Family Act on provisional measures in the national legal system have traditionally been present in a more or less unchanged form, the measures referred to in Article 419(1) of the Family Act are relatively new. ${ }^{80}$ However, we believe that, in addition to general provisions on handling family and status related matters, the courts will recognise them in their practice as available and efficient instruments in the exercise of the right to the protection of the child upon his or her return after the unlawful removal or retention and as ways to facilitate the treatment of competent authorities in cross-border proceedings concerning parental responsibility disputes.

\section{CONCLUSION}

The competent authorities are required to take into account the best interests of the child during the entire return procedure conducted under the Hague Convention on Child Abduction. Taking care of the best interests of the child is also manifested through provisional and protective measures for the protection of the child and its assets, but other persons as well,

77 Enforcement Act (Ovršni zakon), Official Gazette, No. 112/12, 25/13, 93/14, 55/16, 73/17.

78 Dika, M.,Građansko ovršno pravo, I. knjiga, Opće građansko ovršno pravo, Narodne novine, Zagreb 2007, pp. 847-848.

79 Enforcement Act, op. cit. note 77, Article 346(1) and (2).

80 Entered for the first time into the Family Act (Narodne novine, No. 75/14) whose application was suspended by the Decision of the Constitutional Court of the Republic of Croatia No. U-I-3101/2014 of 12 January 2015 such that the execution of all individual acts undertaken pursuant to this Family Act is temporarily suspended. However, they were entered in the unchanged form into the Family Act of 2015, which is now in force. 
usually the parent who removed the child, when necessary. Research within the Project, carried out on a sample of 16 judgments, showed that the courts in a total of 7 cases were expected to decide on a request for a provisional or protective measure and/or legal effect of an already existing measure.

Competent authorities which have no jurisdiction as to the substance of the matter are also authorised to undertake appropriate provisional measures. The basis for this treatment are Article 20 of the Brussels II bis Regulation and Article 11 of the Hague Convention on Measures for the Protection of Children. These measures differ currently in relation to the regime of their recognition and enforcement. In that sense, the competent authorities need an unambiguous answer to the question whether, when the child is habitually resident in an EU Member State, Article 11 of the Hague Convention on Measures for the Protection of Children shall apply, in order that the measures taken may have a cross-border effect. The question will no longer be relevant if the Proposal to recast the Brussels II bis Regulation of 2016 is adopted, causing the provision relating to provisional, including protective, measures to become one of the jurisdiction chapters.

The protection of a child upon the return to the state of his or her habitual residence is based on Article 11(4) of the Brussels II bis Regulation, which stipulates that a court cannot refuse to return a child on the basis of Article 13(b) of the Hague Convention on Child Abduction if it is established that adequate arrangements have been made to secure the protection of the child after his or her return. The possibility of taking such measures depends on the national law of the state and on the particular circumstances of the case. The basis for the proceedings in Croatian national law is set by Article 419 of the Family Act, which prescribes measures to ensure the return of a child or to impede the unlawful removal of a child by a parent. Practice has not yet proved how this provision functions in cross-border cases.

Research conducted within the Project confirmed that the existing global issues regarding the application of regulations on provisional measures in civil and commercial matters are also problematic in the practice of Croatian courts, when dealing cross-border abduction cases. Despite a small sample of court judgments, application difficulties are clearly present. These relate to defining the jurisdiction of the national court to impose provisional, including protective, measures under Article 20 of the Brussels II bis Regulation and to the attitude the court towards provisional measures taken in another Member State with regard to their legal effects in the Republic of Croatia. In addition, it was found that in only two cases the court did take into account Article 11(4) of the Brussels II bis Regulation. This oversight can be only partially justified by the fact that in some cases the Croatian courts used the mechanism referred to in Article 13(3) of the Hague Convention on Child Abduction, but it did not prove efficient in terms of the speed of delivery of the requested data. The solution to the difficulties encountered by the competent authorities lies in the introduction of mandatory concentration of jurisdiction for dealing with cross-border child abduction cases, which is contained in the Proposal to recast the Brussels II bis Regulation, and in conducting continuous and appropriate training of practitioners dealing with cross-border abduction cases. 


\section{REFERENCES}

1. Beaumont, P., Walker, L., Holliday, J., Conflicts of EU Courts on Child Abduction: The reality of Article 11(6)-(8) Brussels IIa proceedings across the EU, Journal of Private International Law, Vol. 12, No. 2, 2016, pp. 211-260.

2. Beaumont, P., Walker, L. and Holliday, J., Parental responsibility and international child abduction in the proposed recast of Brussels IIa Regulation and the effect of Brexit on future child abduction proceedings, International Family Law Journal, Vol. 4, 2016, pp. 307-318.

3. Dika, M., Građansko ovršno pravo, I. knjiga, Opće građansko ovršno pravo, Narodne novine, Zagreb, 2007.

4. Drventić, M., New Trends in European Family Procedural Law, in: Duić, D., Petrašević, T. (eds.), Procedural Aspects of EU Law, Sveučilište J. J. Strossmayera u Osijeku, Pravni fakultet Osijek, Osijek, 2017, pp. 424-447.

5. Honorati, C., Provisional Measures and the Recast of Brussels I Regulation: A Missed Opportunity for a Better Ruling, Rivista di diritto internazionale privato e processuale, No. 3, 2012, pp. 525-544.

6. Kruger, T., Samyn, L., Brussels IIbis: successes and suggested improvements, Journal of Private International Law, Vol. 12, No. 1, 2016, pp. 132-168.

7. Lazić, V., Legal Framework for International Child Abduction in the European Union - the Need for Changes in the Light of Povse v. Austria, in: Župan, M. (ed), Private International Law in the Jurisprudence of European Courts - Family at Focus, Pravni fakultet Osijek, Osijek, 2015, pp. 295-316.

8. Lortie, P., An overview of the aims and central features of the 1996 Hague Convention on International Child Protection, in: Rešetar, B., Aras, S. (eds.), Represivne mjere za zaštitu osobnih prava i dobrobiti djeteta Interdisciplinarni, komparativni i međunarodni osvrti, Pravni fakultet Osijek, Osijek, 2014, pp. 221.-227.

9. McEleavy, P., The New Child Abduction Regime in the European Union: Symbiotic Relationship or Forced Partnership?, Journal of Private International Law, Vol. 1, No. 1, 2005, pp. 5-34.

10. Pataut, E., Article 11 Return of the child, in: Magnus, U., Mankowski, P. (eds.), Brussels IIbis - Commentary, Sellier European Law Publishers, München, 2012, pp. 127-145.

11. Pertegás Sender, M., Article 20 Provisional, including protective measures, in: Magnus, U., Mankowski, P. (eds.), Brussels IIbis - Commentary, Sellier European Law Publishers, München, 2012, pp. 246-256.

12. Schuz, R., The Hague Child Abduction Convention. A Critical Analysis, Hart Publishing, 2013.

13. Župan, M., Roditeljska skrb u sustavu Haške konvencije o mjerama dječje zaštite iz 1996., in: Rešetar, B. (ed.), Pravna zaštita prava na (zajedničku) roditeljsku skrb, Pravni fakultet Osijek, Osijek, 2012, pp. 199-222.

14. Župan, M., Drventić, M., Kindesentführung vor kroatischen Gerichten mit besonderer Rücksicht auf die aus Deutschland kommenden Anträge, Revija za evropsko pravo, Vol. 20, No. 1., 2018, pp. 63-83.

\section{LIST OF REGULATIONS, ACTS AND COURT DECISIONS}

1. Case 143/78, Jacques de Cavel v Louise de Cavel, [1979], ECLI:EU:C:1979:83.

2. Case 25/81, C.H.W. v G.J.H., [1982], ECLI:EU:C:1982:116. 
3. Case C-256/09, Bianka Purrucker v Guillermo Vallés Pérez, [2009], ECLI:EU:C:2010:437.

4. Case C-256/09, Opinion of Advocate General Sharpston delivered on 20 May 2010, ECLI:EU:C:2010:296.

5. Case C-403/09 PPU, Jasna Detiček v. Maurizio Sgueglia, [2009], ECLI:EU:C:2009:810.

6. Case C-523/07, A, [2009], ECLI:EU:C:2009:225.

7. Charter of Fundamental Rights of the European Union, Official Journal of the European Union, [2007], OJ C 303/1.

8. Council Regulation (EC) No 2201/2003 of 27 November 2003 concerning jurisdiction and the recognition and enforcement of judgments in matrimonial matters and the matters of parental responsibility, repealing Regulation (EC) No 1347/2000, [2003], OJ L 338.

9. County Court of Zagreb, No. 1 Gž Ob-1456/2016-2 from 2 December 2016.

10. County Court of Zagreb, No. br. 68 Gž Ob-400/17-2 from 10 April 2017.

11. Enforcement Act, Official Gazette, No. 112/12, 25/13, 93/14, 55/16 73/17.

12. Family Act, Official Gazette, No. 103/15.

13. HCCH, Convention of 19 October 1996 on Jurisdiction, Applicable Law, Recognition, Enforcement and Co-operation in Respect of Parental Responsibility and Measures for the Protection of Children, URL: https://www.hcch.net/en/instruments/conventions/full-text/?cid=70. Accessed 4 September 2017.

14. HCCH, Hague Convention of 25 October 1980 on the Civil Aspects of International Child Abduction, URL: https://www.hcch.net/en/instruments/conventions/full-text/?cid=24. Accessed 5 September 2017.

15. Municipal Civil Court of Zagreb, No. 144-R1 Ob-830/16-43 from 31 January 2017.

16. Municipal Court of Osijek, No. 12 R1 Ob-566/2016-26 from 3 October 2016.

17. Municipal Court of Split, No. R1 Ob-637/2016 from 26 June 2017.

18. Proposal for a Council Regulation on jurisdiction, the recognition and enforcement of decisions in matrimonial matters and the matters of parental responsibility, and on international child abduction (recast), Bruxelles, 30.6.2016, COM(2016) 411 final 2016/0190 (CNS).

\section{REPORTS AND GUIDES}

1. Conclusions and Recommendations of the Fourth Meeting of the Special Commission to Review the Operation of the Hague Convention of 25 October 1980 on the Civil Aspects of International Child Abduction, https://assets.hcch.net/upload/concl28sc4_e.pdf. Accessed 18 September 2017.

2. Draft Guide to Good Practice on Article 13(1)(b) of the Hague Convention of 25 October 1980 on the Civil Aspects of International Child Abduction, Seventh Meeting of the Special Commission on the Practical Operation of the 1980 Child Abduction Convention and the 1996 Child Protection Convention, https://assets.hcch.net/docs/0a0532b7-d580-4e53-8c25-7edab2a94284.pdf. Accessed 27 September 2017.

3. Explanatory Report on the Convention, drawn up on the basis of Article K.3 of the Treaty on European Union, on Jurisdiction and the Recognition and Enforcement of Judgments in Matrimonial Matters (approved by the Council on 28 May 1998) prepared by Dr Alegría Borrás, [1998] OJ C $221 / 27$. 
4. Guide to Good Practice under the Hague Convention of 25 October 1980 on the Civil Aspects of International Child Abduction, Part I - Central Authority Practice, HCCH Publications, 2003, https://assets. hcch.net/upload/abdguide_e.pdf. Accessed 17 September 2017.

5. Kruger, T., Enhancing Cross-Border Cooperation, Recasting the Brussels IIa Regulation, Workshop 8 November 2016, Compilation of briefings for the JURI Committee, 2016, http://www.europarl. europa.eu/RegData/etudes/STUD/2016/571383/IPOL_STU(2016)571383_EN.pdf. Accessed 25 September 2017.

6. Lagarde, P., Explanatory Report on the 1996 Hague Child Protection Convention, HCCH Publications, 1998, https://www.hcch.net/en/publications-and-studies/details4/?pid=2943. Accessed 21 September 2017.

7. Pérez-Vera, E., Explanatory Report on the 1980 Hague Child Abduction Convention, HCCH Publications, 1982, https://assets.hcch.net/upload/expl28.pdf. Accessed 17 September 2017.

8. Practical Handbook on the Operation of the 1996 Child Protection Convention, HCCH Publications, 2014, https://www.hcch.net/en/publications-and-studies/details4/?pid=6096\&dtid=3. Accessed 19 September 2017.

9. Practice Guide for the Application of the Brussels IIa Regulation, http://ec.europa.eu/justice/civil/files/ brussels_ii_practice_guide_hr.pdf. Accessed 20 September 2017. 
Mirela Župan*

Senija Ledič

Martina Drventic

\section{PRIVREMENE MJERE I POSTUPCI OTMICE DJECE}

\section{Sažetak}

Svrha uspostavljenog sustava za postupanje u slučajevima međunarodne otmice djece, utvrđenog Haškom konvencijom o otmici djece, koja je u odnosu na države članice EU osnažena odredbama Uredbe Brussels IIbis, je osiguranje žurnog povratka djeteta u državu članicu iz koje je protupravno odvedeno. Postupak povratka i predaje djeteta mora osigurati punu zaštitu djeteta kako u državi nezakonitog boravišta tako i u državi u koju se dijete ima vratiti. Nadležnim tijelima u tim okolnostima na raspolaganju stoje pravni mehanizmi privremenih i zaštitnih mjera predviđeni Uredbom Brussels IIbis te Haškom konvencijom o mjerama za zaštitu djece. Mogućnost poduzimanja takvih mjera ovisit će o nacionalnom pravu države i o posebnim okolnostima slučaja. Kroz rad će biti prikazan pravni okvir za izricanje privremenih mjera u slučajevima prekogranične otmice koji će biti potkrijepljen praksom Suda pravde Europske unije. Na primjerima iz sudske prakse prikupljene u okviru projekta „Prekogranično odvođenje i zadržavanje djece - hrvatska praksa i europska očekivanja“"kroz rad će biti prikazane poteškoće s kojima se u primjeni relevantnih odredbi susreću sudovi u Republici Hrvatskoj.

Ključne riječi: $\quad$ prekogranična otmica djece, Haška konvencija o otmici djece, Uredba Brussels IIbis, Haška konvencija o mjerama za zaštitu djece, privremene i zaštitne mjere, Sud pravde Europske unije

\section{(c) (i) (8)}

This work is licensed under a Creative Commons

Attribution-NonCommercial 4.0 International License.

* $\quad$ Dr. sc. Mirela Župan, izvanredna profesorica na Katedri za međunarodno javno i privatno pravo, Pravni fakultet, Sveučilište Josipa Jurja Strossmayera u Osijeku, Stjepana Radića 13, 31000 Osijek, Republika Hrvatska. Adresa e-pošte: mzupan@pravos. hr. ORCID: https://orcid.org/0000-0002-6673-1274

** Mr. sc. Senija Ledić, sutkinja, Županijski sud u Splitu, Gundulićeva 29a, Republika Hrvatska. Adresa e-pošte: Senija.Ledic@zsst. pravosudje.hr. ORCID:https://orcid.org/0000-0003-4919-1963

*** Martina Drventić, mag. iur., mlađi istraživač na EUFam projektu, Pravni fakultet, Sveučilište Josipa Jurja Strossmayera u Osijeku, Stjepana Radića 13, 31000 Osijek, Republika Hrvatska. Adresa e-pošte: mdrventic@pravos.hr. ORCID: https://orcid. org/0000-0002-0880-0382 